\title{
Küçük Konaklama İşletmelerinde Pazarlama Stratejileri ve Müşteri Bağlılı̆̆ı: İzmir Örneği
}

\author{
Marketing Strategies and Customer Loyalty in Small Accomodation \\ Enterprises: Case of İzmir
}

Övünç Bardakoğlu, Dokuz Eylül Üniversitesi, Türkiye, ovuncbardakoglu@hotmail.com

Öz: Turizm sektöründe diğer tüm sektörlerde olduğu gibi işletmeler nihai hedef olan karlllı̆̆a ulaşmak amactyla pazarlama faaliyetleri üzerinde özenle durmaktadırlar. Farklı ölçeklerdeki konaklama işletmelerinin kullandı̆̆ pazarlama araçları değerlendirildiğinde bazı farklılıkların ortaya çıktı̆̆̀ gözlenmektedir. Bu çalışmanın amacı İzmir'de faaliyet gösteren butik hizmet sunan 23 küçük konaklama işletmesinin pazarlama stratejilerinde kullandı̆̆g araçları ve müşseri bağlllığını nasıl sağladıklarını belirlemektir. Bu doğrultuda işletme sahip ya da yöneticileriyle yüz yüze görüşülmüş, elde edilen veriler içerik analizine tabi tutulmuştur. Ağızdan kulağa pazarlama, tanıtım, reklam ve sosyal medyanın küçük konaklama işletmeleri tarafindan en çok tercih edilen pazarlama araçları olduğu ve otel sahibi tarafindan karşılanma, konaklama süresince yakından ilgilenilme ve veri tabanı oluşturarak iletişimin sürekli hale getirilmesinin ise müşteri bağlllığını arttıran unsurlar olduğu saptanmıştır.

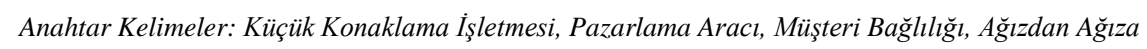

Abstract: In the tourism sector, like in all other sectors, enterprises are diligently focuse on marketing activities in order to achieve profitability which is their ultimate goal. When marketing tools that are used by various scales of accomodation enterprises are assessed, it is observed that some differences are emerged. The aim of this study is to determine the tools that are used in marketing strategies of 23 small accomodation enterprises which are operated in Izmir and offer boutique service and the way they provide customer loyalty. In this regard, owners or managers of the enterprises were interviewed face-to-face and the data obtained were content analyzed. It is determined that, word of mouth marketing, promotion, advertising and social media are the most prefered marketing tools among small accomodation enterprises and welcoming by hotel owner, close attention during the accommodation process, keeping in touch continuously by creating a data base are the factors that increase customer loyalty.

Keywords: Small Accommodation Enterprise, Marketing Tool, Customer Loyalty, Word of Mouth

\section{Giriş}

Turizm olayının gelişmesi ile birlikte insanların yer değiştirmelerinden kaynaklanan geçici konaklama ihtiyaçları ortaya çıkmıştır. Hanlar ve kervansaraylar olarak görülen ilk konaklama işletmeleri geçen zaman ve değişen tüketici eğilimleri ile birlikte gelişme göstermiştir (Usta, 2008). Günümüze gelindiğinde, lüks ve büyük işletmelerden ev pansiyonculuğuna kadar çok geniş bir yelpaze içinde tüketicinin tercih edebileceği birbirinden farklı büyüklük ve fiyatta konaklama işletmesi mevcuttur (Olalı ve Korzay, 1993). İşletmelerin pazarda iyi bir konuma sahip olabilmeleri nitelikli hizmet sunumuna bağlıdır (Özel, 2012; Taş, 2015). Bu kadar fazla seçeneğin varlığı işletme sahip ve yöneticilerini pazar paylarını korurken zorlamaktadır(İçöz, 2001). Yeni pazarlara girerek potansiyel tüketicilere ulaşmak ve mevcut müşterileri sürekli müşteri durumuna getirmek son derece önemlidir.

Pazarlama faaliyetleri üretim yapılan sektörlerde en önemli faaliyet alanlarından birisidir. Pazarlamadaki temel hedef müşteriye doğru ürünle ulaşmak, tüketimin gerçekleşmesini sağlamak ve tüketiciyi memnun etmektir. Turizm sektörü de hizmet üretiminin esas olduğu bir sektör olarak turistik ürün ve faaliyetlerin dolayısı ile işletmelerin pazarlanması nihai hedef olan karlılığa ulaşılması açısından son derece önemlidir. Konaklama işletmeleri kullanacakları pazarlama araçlarını belirlerken hedeflenen pazarın iyi tanımlanması, istikrarlı bir fiyat politikası oluşturulması, müşterilerden gelen talepler doğrultusunda ürünlerin geliştirilmesi konularına dikkat etmelidirler (Hacıoğlu, 1991). Çünkü değişen turizm eğilimleri, turist taleplerindeki farklılaşma, sertleşen rekabet koşulları işletmelerin farklı ürün ve hizmet sunumuna yönelmesini zorunlu kılmaktadır.

Turistik ürünü arz eden konaklama işletmeleri açısından yer, ortam, hizmeti sunan personelin görünüş ve tavırları, hizmet kalitesi gibi unsurlar pazarlama iletişiminin önemli bir boyutunu oluşturur (Güler, 2009). Dolayısı ile konaklama işletmelerinin pazarlama faaliyetlerini planlarken bu unsurlardan yola çıkmaları akıllıca olacaktır. Etkili bir pazarlama çalışması müşterinin işletmeye gelmesini sağlarken, işletmede sunulan kaliteli ve tatmin edici hizmet müşteri bağlılığ yaratır.

Araştırma kapsamında ilgili literatür incelendiğinde yönetici bakış açısıyla küçük konaklama işletmelerinin pazarlama stratejileri ve müşteri bağlılığı konularında bir inceleme yapılmadığı belirlenmiştir. Bu doğrultuda küçük konaklama işletmelerinde kullanılan pazarlama araçlarından; ağızdan kulağa pazarlama, reklam, tanıtım, elektronik pazarlama ve müşteri memnuniyeti ve bağlılı̆̆ı kavramlarıyla ilgili literatür taranmış, İzmir il sınırları içinde bulunan ve butik ağırlama hizmeti sunan küçük konaklama işletmelerinin sahip ya da yöneticileri ile yüz yüze görüşülmüştür. 


\section{Konaklama İşletmelerinde Pazarlama Stratejileri}

Pazarlama faaliyeti; işletmelerin üretmiş oldukları ürünleri mevcut ya da potansiyel tüketicilere ulaştırmak ve satmak üzere gerçekleştirdikleri eylemlerdir (İçöz, 2001). İşletmelerin öncelikli amacı hedef pazarların istek ve beklentilerini belirleyerek farklı pazarlama araçları ile tüketiciye ulaşmak ve tüketim sonunda tatmin edebilmektir (Kozak, 2010). Modern pazarlama anlayışı tamamen tüketici odaklı olarak şekillenmekte ve pazarlama yöneticileri tarafından müşterinin istek ve beklentileri ilk sıraya konmaktadır. Başlangıçta pazarlama literatürü içerisinde mal ve hizmet pazarlaması aynı algılanırken, hizmetler sektörünün gelişmesi, istihdam imkanlarının artması ile birlikte son yıllarda mal ve hizmet pazarlaması birbirinden ayrı değerlendirilen kavramlar olmuştur (İçöz, 2005). Çünkü hizmetler kendilerine has bazı özellikleri ile mallardan farklılaşmakta dolayısı ile pazarlama şekilleri de değişmektedir.

Hizmetler sektöründe hizmeti alan ve sunanın insan olması tüketici ve personel arasında etkin iletişimin kurulması iyi bir hizmet pazarlama faaliyetinin gerekliliğidir (İçöz, 2005). Turizm sektörü de hizmetler sektörünün bir alt sektörü olması (Olalı ve Timur, 1989) nedeniyle turistik ürünlerin pazarlanmasının normal mal pazarlamasından farklılaştı̆̆ görülmektedir. Turizm sektörünün gelişmesi turistik ürünün kalitesine ve başarılı bir strateji ile pazarlanmasına bağlıdır (Navickas ve Malakauskaite, 2009). Böylece söz konusu turistik destinasyon ya da işletme turizm piyasasında iyi bir konuma gelebilir (Goeldner ve Ritchie 2003; Benur ve Bramwell,2015). Turizm pazarlaması pek çok açıdan hizmet pazarlaması ile benzer özellikler taşırken turistik ürünün özelliği ve dağıtım kanallarındaki farklılıklara dayalı olarak bazı noktalarda ayrılmaktadır (Kozak, 2010).

Turizm pazarlaması bir işletmenin en yüksek karlılık hedefine uygun olarak sunulan turistik ürünün, hedeflenen pazardaki talep yapısına bağlı olarak pazarda iyi bir yer edinmesini sağlama çabalarıdır (İçöz, 2001). Turizm pazarlamasının başlangıç aşamasını tüketici isteklerinin iyi analiz edilerek ürün arzının planlanması oluşturur (Dolnicar ve Ring, 2014; Hudson ve Thal, 2013). İşletmeler nihai hedef olan karlılığa ulaşabilme amacı ile mevcut turizm talebinin özellikleri üzerinde hassasiyetle durmalıdırlar (Kozak, 2014; Şahin ve Şengün, 2015). Turizm sektörünün ulaşmış olduğu uluslararası boyutlar ve giderek sertleşen rekabet koşulları işletmelerin turizm pazarlarında daha etkin olabilmeleri açısından pazarlama faaliyetlerinin önemini arttırmaktadır (İçöz, 2001).

Konaklama işletmeleri turizm sektörünün önemli bir aktörü olarak (Olalı ve Korzay, 1993), pazarlama faaliyetlerinin dikkatli ve etkin yapılması gerektiği alanlardan biridir. Bu noktada yine turizm ürününün kendine özgü yapısı (dağıtım kanalı farklılığı, depolanamama, talepteki mevsimsel değişimler, faaliyet çevresi vb) göz önünde bulundurularak pazarlama çalışmaları başlatılmalı ve bu doğrultuda yönlendirilmelidir (Kozak vd., 2002). Pazarlama faaliyetleri konaklama işletmelerine; pazar araştırmasının sürekliliği, yeni ürün geliştirme, satış arttırma ve kontrol gibi konularda önemli katkılar sağlar (Hacıŏlu, 1991).

Konaklama işletmelerinde pazarlama faaliyetlerinin kısa sürede başarıya ulaşabilmesi için mevcut durum analizi, pazarlama amaçlarının ve hedef pazarların doğru belirlenmesi konuları üzerinde özenle durulması gerekmektedir (Kozak vd., 2002). Ancak her alanda olduğu gibi turizm sektöründe de farklı büyüklükteki işletmelerin pazarlanmasından farklılıklar görülmektedir (Usta, 2008). Küçük konaklama işletmelerinde hem personel sayısının hem de bölümlerin azlığı nedeni ile genellikle ayrı bir satış ve pazarlama bölümü bulunmaz. Pazarlama faaliyetleri büyük ölçüde işletmenin yönetici ya da sahibi ve diğer personel tarafından yürütülür. Bu nedenle ağızdan kulağa (word of mouth) pazarlama en etkili yöntemlerden biridir (Buttle, 1998; Papadimitriou, Kaplanidou ve Apostolopoulou 2015). Büyük konaklama işletmeleri pazar araştırması, hedef pazar belirleme, pazar bölümleme, pazarda konumlanma gibi araştırma ve geliştirmeye dayalı pazarlama tekniklerine yönelirken, küçük konaklama işletmeleri daha düşük maliyetlerle gerçekleştirilecek reklam, tanıtım, elektronik pazarlama gibi pazarlama araçlarını kullanma eğilimindedirler (İçöz, 2001).

\section{1. Ă̆gzdan Kulăga Pazarlama}

Ağızdan kulağa pazarlama tüketicin ürün, hizmet ya da işletme hakkındaki yorumlarını yakın çevresine ya da çeşitli çevrimiçi kanallar aracılığı ile potansiyel tüketicilere resmi olmayan şekilde aktarmasıdır (Buttle,1998; Derbaix ve Vanhome, 2003,). Güvenilirlik, deneyim aktarımı, tüketici odaklılık, zaman ve para tasarrufu özellikleri ile son derece güçlü ve ikna edici bir iletişim aracı olan ağızdan kulağa pazarlama ve çevrimiçi tüketici yorumları turizm sektöründe çok daha geniş kitlelere hızla ulaşması nedeniyle çok değerli bir pazarlama aracı olarak kabul görmektedir (Kutluk ve Avcıkurt, 2014). Turistler ağızdan kulağa tavsiyelerin ticari bir amaç gütmemesi nedeniyle güven verici ve doğru olduğunu düşünürler. Tatilden mutlu dönen turist en etkili ve düşük maliyetli pazarlama aracıdır. Çünkü iyi geçen bir tatil deneyimi mutlulukla ve çok kez tekrarlanarak paylaşılacak bu da potansiyel birçok tüketiciye, işletme tarafından başka bir maliyete katlanmadan, ulaşılmasını sağlayacaktır (Confente, 2015). Bu nedenle küçük konaklama işletmelerinin ağırladıkları misafirlerine eşsiz bir tatil deneyimi yaşatarak işletmeden mutlu ayrılmalarını sağlamaları etkin bir pazarlama faaliyetinin ilk koşulu olarak görülmektedir. İşletme tarafından pazarlama faaliyeti için ek bir bütçe oluşturmadan sadece konuk ağırlamayı kaliteli hizmet sunumu ile gerçekleştirerek çok geniş kitlelere ulaşabilmek mümkün olmaktadır. 
Ağızdan kulağa pazarlama işletmeler açısından neredeyse bir maliyet gerektirmeyen ve tüketicinin satın alma kararı üzerinde çok hızlı etki edebilen bir araçtır (Stokes ve Lomax, 2002; Arlı, 2012). Özellikle bilgisayar merkezli iletişimin gelişmesi ile birlikte kişisel görüş ve yorumlar sanal ortamda paylaşılmaya başlanmış böylece de daha fazla tüketiciye hızlı bir şekilde ulaşma imkanı doğmuştur (Sarışık ve Özbay, 2012). Bu durum pazarlama faaliyetine ayrılan bütçeyi azaltırken, buradan artan payın personel, kaliteli malzeme tedariği gibi gider kalemlerine aktarılması sağlanarak müşteri mutluluğu bir ölçüde garantiye alınmış olur.

\subsection{Tutundurma Faaliyetleri}

Konaklama işletmeleri tutundurma araçları sayesinde tüketici ile hızlı bir iletişim kurabilmektedirler (Kozak vd., 2002). Sunulan hizmetin soyut nitelikte olması bir yandan tutundurma faaliyetlerinin önemini arttırırken, diğer yandan zorlaştırmaktadır. İşletme sahip ya da yöneticileri potansiyel tüketicilere ulaşmak, tüketim için istek uyandırmak, işletmenin bilinirliğini arttırmak, pazarda olumlu bir imaj oluşturabilmek adına farklı yöntemler denemektedir. Reklam da işletmeler tarafindan sıklıkla kullanılan tutundurma araçlarından biridir (Kotler vd., 1996). Konaklama işletmesinin belli ücret karşılığında hedeflenen pazardaki potansiyel tüketiciye ulaşmak amacıyla farklı kitle iletişim araçlarının kullanılması ile gerçekleşen reklam faaliyetleri turizm sektöründe en fazla tercih edilen yöntemler arasındadır (Kozak vd., 2010).

Reklam pazarlama faaliyetleri içinde en yüksek maliyetli araçtır (Abbey, 1998). Doğru bir reklam kampanyası yürütülebilmesi ve tüketiciye doğru mesajın iletilebilmesi için konaklama işletmeleri profesyonel reklam ajansları ile çalışmayı tercih etmektedirler (İçöz, 2001). Böylece doğru zamanda, doğru yerde, doğru hedef kitleye ulaşılarak reklam giderleri için katlanılan maliyetin karşılığı alınabilir. Gazete, dergi, televizyon kanalları, radyo gibi görsel, işitsel ve yazılı medya araçları (Tek, 1999) reklam için halihazırda kullanılsa da günümüzün en yaygın kitle iletişim aracı bilgisayar ve dolayısı ile internet ortamıdır.

Diğer bir etkili tutundurma aracı ise tanıtımdır. Bir işletme ya da destinasyonla ilgili olumlu imaj yaratmak, bilinirliğini artırmak amacıyla belli bir plan içinde gerçekleştirilen sistemli faaliyetlerdir (Kozak vd., 2002). Tanıtım çalışmaları ulusal ve uluslararası düzeyde çeşitli kurumlar aracılığı ile gerçekleştirilir.

\subsection{Elektronik Ortamda Pazarlama}

Turizm sektöründe pazarlama faaliyetleri içinde internet ortamında farklı araçlar kullanılarak yapılan elektronik pazarlama en yaygın ve işlevsel pazarlama biçimidir. İşletmelerin kendilerine ait web sayfaları, çevrimiçi satış kanalları, sosyal medya günümüz pazarlama anlayışında küçük konaklama işletmeleri tarafından sıklıkla tercih edilmektedir. Konaklama işletmeleri web sayfalarından rezervasyon, satış, müşteri ilişkileri gibi her türlü doğrudan pazarlama faaliyetini gerçekleştirebilmektedir (Kozak, 2010). Turist seyahat aracısı kullanmak yerine doğrudan işletmeyle bağlantıya geçip konaklamasını kendi planlamayı tercih etmekte bu da işletmelere ciddi bir maliyet avantajı sağlamaktadır.

Son yıllarda teknolojinin hızlı gelişmesi ve tüketicilerin çok daha fazla internet kullanmaya başlaması pazarlama aracı olarak da kullanılabilen yeni platformların oluşmasına neden olmuştur (Karamehmet, 2013). Sosyal medya bu araçlar arasında en yaygın kullanım oranına sahip çevrimiçi kaynaktır (Şanlı̈̈z vd., 2013). Sosyal medya hedef pazarın katılımının olduğu geliştirilebilir, etkileşimli, içinde toplulukları barındıran ve birbirine bağlayan çevrimiçi iletişim kanalıdır (Eröz ve Doğdubay, 2012). Gerek ulusal gerekse de uluslararası turizm pazarından pay alabilmek için geleneksel pazarlama araçlarının (gazete, radyo, televizyon, katalog, broşür vb.) yanı sıra elektronik posta, kısa mesaj, sosyal medya gibi iletişim araçlarından faydalanmak gereklilik haline gelmiştir.

İşletmeler mevcut müşterileri ile iletişimi sürdürmek, potansiyel tüketicilere ulaşmak, güven vermek, bilinirliklerini arttırmak, marka imajlarını korumak adına sosyal medya araçlarını gün geçtikçe daha fazla kullanma eğilimindedir (Barutçu ve Tamaş, 2013). Sosyal medya kullanımının getirdiği en önemli üstünlüklerden biri de düşük maliyet ve yüksek fayda imkanı taşımasıdır.

\section{Müşteri Memnuniyeti ve Bağlılığı}

Konaklama işletmelerinde ürünün bileşik bir yapıda olması hizmet kalitesini ve memnuniyet düzeyini etkilemektedir (Kılıç ve Eleren, 2009). Kaliteli hizmet tüketicinin algıladığı hizmetten tatmin olma derecesi ile ilgilidir. Tüketiciler tarafından hizmet değerlendirilirken sunum süreci de göz önünde bulundurulmaktadır. Hizmet kalitesi işletmenin müşteri beklentilerini karşılayabilme veya aşabilme yeteneğidir (Öztürk ve Seyhan, 2005b). Bu nedenle hizmeti sunan personelin müşteriyi nasıl memnun edeceğinin bilincinde olması ve bu doğrultuda davranması memnuniyet düzeyini arttıracak dolayısı ile söz konusu işletmeye bağlılık sağlayacaktır.

Müşteri tarafından beklenen hizmet ve algılanan hizmet arasındaki ilişki; güvenilirlik, ilgi, yetenek, ulaşılabilirlik, nezaket, iletişim, inanılırlık, güvenlik, anlaşılabilirlik, somut özellikler olmak üzere on boyutu içermektedir (Parasuraman vd., 1985). Müşteri konakladığı işletmede bu boyutların hepsini yüksek dereceli algılarsa aldığı hizmeti kaliteli olarak ifade eder. Küçük konaklama işletmeleri az konuğa hizmet etmeleri nedeni ile birebir iletişim kurulması, 
ilgili davranılması, sorunların hızlı ve etkili çözülebilmesi gibi gerekçelerle hizmet kalitesi düzeylerini çok daha kolay arttırabilmektedirler.

Müşteri memnuniyeti tüketicinin ürün yada hizmetten beklentisi ile elde ettiği hizmetin örtüşmesi ile ortaya çıkan psikolojik bir kavramdır (Kotler vd., 1996). Ürün ya da hizmetin performansı beklentinin gerisine düşerse tatminsizlik oluşur ve tüketici işletmeden memnuniyetsiz ayrılır (Fornell, 1992). Bu da hem müşteri bağlılığı yaratılmasında hem de potansiyel müşterilerin işletmeye çekilmesinde zorluğa neden olur (Tütüncü, 2001). Özellikle gelişmekte olan ülke ekonomilerinde müşteri memnuniyeti işletme başarısı ile neredeyse eş anlamlı olarak algılanmaktadır (Kobylanski, 2012). Bu nedenle yöneticiler müşteri beklentilerini yerine getirebilme amacı ile son derece titiz davranmaktadır. Müşterinin algıladığ 1 hizmet kalitesi doğrudan memnuniyetini etkilediği için ürünlerin sunumunda işletme tarafindan en yüksek performansın sunulması gerekmektedir (Wong ve Dioko, 2013; Taplin, 2013). Tüketici istek ve ihtiyaçlarının doğru şekilde belirlenmesi, bu istekler doğrultusunda ürünlerin oluşturulması tüketicinin ürünü rakiplerinden farklı algılamasını dolayısı ile memnuniyetin oluşmasını sağlar (Özer ve Günaydın, 2010). Konaklama işletmeleri; pazarlama faaliyetleri için çok önemli olan müşteri memnuniyetini sağlamak amacıyla tüketicilerle yoğun bir iletişim içinde bulunarak memnuniyeti arttırmak ve sonunda sadık müşteriler kazanmaya çalışmaktadırlar (Kotler vd., 1996). Küçük konaklama işletmeleri de az müşteriye hizmet verdikleri için birebir iletişim kurarak memnuniyet düzeyini kolaylıkla yükseltebilme imkanına sahiptirler. Turizm sektöründe işletmeler hedef pazarda oluşturdukları beklenti düzeyi konusunda hassas davranmalıdır (Kotler vd., 1996). Olduğundan yüksek beklenti düzeyi yaratılırsa tüketici tatmininde zorlanılabilir düşük beklenti düzeyinde ise tüketici baştan ürünü tüketmekten vazgeçebilir. Müşteri tatmini müşteri memnuniyeti için bir ön koşuldur (Oliver, 1980).

Turizm sektöründe her geçen gün sertleşen rekabet koşulları işletmelerin varlıklarını sürdürebilmek adına mevcut müşterilerini sadık birer müşteri haline getirmeye yönlendirmektedir (Kotler vd., 1996). Müşteri bağlılığ1; tüketicinin bir işletmenin ürünlerini tekrar tüketme eğiliminde olması ve ağıdan kulağa iletişimle çevresine tavsiye etmesi şeklinde ifade edilebilir (Tütüncü, 2001). İşletme yöneticileri açısından memnuniyet, müşteri bağlılığına ulaşabilmek adına ön koşul olarak görülmektedir (Taplin, 2013). Sadık müşterilerin olumlu ağızdan kulağa iletişim aracılığıyla potansiyel tüketicileri işletmeye çekmesi bağlılığın önemli bir faydasını oluşturur (Selvi ve Ercan, 2006). Müşteri bağlılığ1 davranışsal bağlılık ve tutumsal bağlılık olarak iki boyut içermektedir. Davranışsal bağlılıkta tekrar satın alma söz konusu iken; tutumsal bağlllıkta yakın çevreye tavsiye etme mevcuttur (Kim, Vogf ve Knutson 2015; Bowen ve McCoin, 2015; Kandampully, Zhang ve Bilgihan, 2015). Konaklama işletmesinden memnun olmuş bir şekilde ayrılan tüketici tekrar otele gelmeyi arzu etmekte ve güzel geçen tatilini sosyal çevresi ile paylaşarak tavsiyede bulunma davranışını göstermektedir (Özer ve Günaydın, 2010).

Müşteri bağlılığı oluştuktan sonra tüketici rakip işletmeler tarafindan yapılan tekliflere ve ısrarlara karşı dirençli hale gelir. Mevcut müşterilerin sadık hale getirilmesi, potansiyel müşterilere ulaşma çabalarına göre çok daha düşük maliyetlidir (Kim, Vogf ve Knutson 2015). Müşteri memnuniyetinin sağlanmasında ürün ya da hizmetin kalitesi son derece önemlidir (İçöz, 2005). Müşteri bağlılığını arttıran unsurlardan bir diğeri de müşteriyi onurlandırma ve ödüllendirmedir (Öztürk ve Seyhan, 2005a). Konaklama işletmesine gelen müşterilerin elektronik posta ve adresleri alınarak önemli günlerde tebrik mesajları gönderilmesi, sürekli gelen müşteriye çeşitli sürprizler ve özel indirimler yapılması tüketicinin işletmeye bakış açısını değiştirerek bağlılığını arttıracaktır.

\section{Yöntem}

$\mathrm{Bu}$ araştırmanın amacı küçük konaklama işletmelerinde yöneticilerin bakış açısıyla; uygulanan pazarlama stratejilerinin belirlenmesi ve müşteri bağlılığına ne ölçüde önem verildiğinin saptanmasıdır. Bu doğrultuda ilgili literatür taranmış ve 23 butik hizmet sunan küçük konaklama işletmesi ile görüşülmüştür. Çalışma kapsamında "işletmenizde uyguladığınız pazarlama stratejileri nelerdir?" ve "müşteri bağlılığını sağlamak için ne yapıyorsunuz?" araştırma sorularına yanıt aranmıştır. Örneklem belirlenirken amaçlı örnekleme yönteminden maksimum çeşitlilik örneklemesi tercih edilmiştir.

Uygulama İzmir şehir merkezi, Çeşme , Alaçatı, Seferihisar, Urla, Foça ve Selçuk ilçelerinde bulunan 23 küçük konaklama işletmesinin sahip ya da yöneticileri ile yüz yüze mülakat tekniği ile gerçekleştirilmiştir. 2015 Mayıs ve Haziran aylarında 26 otel sahip/ yöneticisinden randevu talep edilmiş, 2 yönetici sezonun başlamasını gerekçe gösterip randevu vermemiş, 1 yönetici ise görüşmeyi kabul ettiği halde randevu saatinde çok yoğun olduğunu belirterek çalışmaya katılmaktan vazgeçmiştir. Randevu alınan 23 otel sahibi/ yöneticisi ile otellerinde görüşmeler gerçekleştirilmiştir.

35 ile 80 dakika arasında süren görüşmelerin hepsi katılımcıların verdiği izin doğrultusunda ses kayıt cihazı ile kaydedilmiş ve sonrasında yazılı hale getirilmiştir. Yazılı hale getirilen veriler içerik analizi yöntemi ile kodlara ve kodlardan oluşan temalara dönüştürülmüştür. İçerik analizinde amaç birbiriyle ilişkili kavramları bir araya getirerek bu kavram ve temalar çerçevesinde ortaya çıkan sonuçları düzenleyerek yorumlamaktır (Yıldırım ve Şimşek, 2008). Bu doğrultuda görüşmelerden elde edilen veriler ile yazar tarafından oluşturulan kod ve temalar, konunun uzmanı iki akademisyenin aynı veri seti üzerinde birbirinden bağımsız şekilde oluşturduğu kod ve temalar ile karşılaştırılmış ve benzer sonuçlara ulaşıldığı görülmüştür. 
Çalışma kapsamında belirlenmiş olan " işletmenizde uyguladığınız pazarlama stratejileri nelerdir?" ve "müşteri bağlılığını sağlamak için ne yapıyorsunuz?" araştırma sorularına yanıt aranırken, katılımcılara yöneltilen sorular şu şekildedir:

1. İşletmenizde hangi pazarlama araçlarını kullanıyorsunuz?

2. Müşteri üzerinde hangi pazarlama aracının daha etkili olduğunu düşünüyorsunuz?

3. Müşteri bağlılığı sizin için önemli mi? Müşteri bağlılığını sağlamak için neler yapıyorsunuz?

4. İşletmenizde kullanılan pazarlama araçları müşteri memnuniyeti ve bağlılığı konusunda etkili mi?

\section{Bulgular}

Çalışmaya katılan küçük konaklama işletmelerinin sahip ya da yöneticileri ile yapılan görüşmeler sonucunda elde edilen bulgular, belirlenen tema ve kodlar ile ilgili açıklamalar şu şekildedir.

\section{1. Ă̆ızdan Kulă̆a Pazarlama}

Görüşmeye katılan 23 küçük konaklama işletmesinden \%86.9'u ağızdan kulağa pazarlama tekniğinin en fazla tercih edilen yöntem olduğunu ifade etmişlerdir. Ağızdan kulağa pazarlama teması altında ortaya çıkan kodlar; yerel tatlar (\%69.5), mutlu müşteri (\%65.2), kahvaltı (\%60.9), kaliteli hizmet (\%56.5), kaliteli ürünler (\%47.8), temizlik (\%43.4) ve ev yapımı ürünler $(\% 39.1)$ şeklindedir.

İşletme yöneticileri müşterinin işletmede yaşadığı deneyimleri potansiyel tüketicilere aktarması yolu ile gerçekleşen ağızdan kulağa pazarlamanın pozitif yönde etkili olabilmesi için öncelikle müşteriyi mutlu edecek bu koşulların sağlanması gerektiğini belirtmişlerdir. Küçük konaklama işletmeleri genellikle 'oda kahvaltı' hizmet verdikleri için, kahvaltının hazırlanması, sunumu ve kullanılan ürünler konusunda çok hassas davranmaktadırlar. Böylece konukların hem güne iyi başlamaları hem de zihinlerinde oluşacak olumlu imaj için ilk ve önemli adım atılmış olur. Ayrıca küçük konaklama işletmelerinin hemen hemen hepsinin verdiği öğün olan kahvaltı, otelin lezzetli ve kaliteli ürünler sunması ya da kahvaltıda misafirlerine sunacakları esneklikler ile otele farklılık yaratma imkanı sunmaktadır.

"Konuklarımı istedikleri saatte kahvaltı yapabilirler, şu saatte şurada olacaksın kısıtlaması yapmıyoruz. Ayrıca açık büfe kahvaltıya da karşıyı, kahvaltıyı misafirimizin istediği anda hazırlıyor ve masaya istediği kadar servis ediyoruz".

Özellikle İzmir ilçelerinde (Çeşme , Alaçatı, Seferihisar, Urla, Foça ve Selçuk) faaliyet gösteren işletmelerin bulundukları yöreye has ve ev yapımı ürünler sunmaya özen göstermeleri ulaşılan bulgular arasındadır. Çünkü günlük hayatından uzaklaşmak isteyen turist, bir aile büyüğü tarafından yapılmış hissi uyandıran yiyecekleri tüketmeyi tercih etmekte ve bu kendisine sunulduğunda daha çok mutlu olmaktadır. Tüm bunlar kaliteli bir hizmet sunumu ile birleştiğinde turistin işletmeden ayrıldığ 1 anda olumlu ağızdan kualğa iletişime geçmesini kolaylaştırmaktadır.

"Mutlu müşteri hem kendi tekrar geliyor hem de yeni müşterilerin gelmesini sağllyor, daha etkili bir pazarlama aracı düşünemiyorum".

\subsection{Reklam}

Turizm sektöründe kullanılan önemli tutundurma araçlarından biri olan reklama karşı küçük konaklama işletmelerinin bakış açılarının sektörün geneline göre farklılık gösterdiği saptanmıştır. Çalışamaya katılan işletme yöneticilerinin \%43.4'ü sadece piyasada iyi bilinen turizm ve seyahat dergilerine reklam verdiklerini, \%34.7'si ise profesyonel reklam ajansları ile çalıştıklarını ifade etmişlerdir. \%30.4 oranındaki katılımcı küçük oteller kitabında yer aldıklarını belirtmiştir. Bilgili, kültürlü, okumaya önem veren, tatile çıkmadan tatilini planlayan turist profiline ulaşma amacında olan yöneticiler bu kitabın oldukça önemli olduğuna vurgu yapmıştır. "Küçük oteller kitabına ilk giren otellerden biriyiz, 2 yıl önce çıkmak istedik izin vermediler. Otelimizin marka değeri kitabın prestiji açısından önemli imiş, şimdi isteğimiz dışında ama ücret ödemeden hala kitabın içindeyiz".

Katılımcıların \%26'sı ise ulusal ve uluslararası gazete ve dergi yazarlarının işletmenin olduğu bölgeye getirilerek ağırlanmasının (press trip düzenlenmesinin) etkili olabileceğini ifade etmişlerdir.

"Artık kimse büyük paralar ödeyerek reklam yapmayı tercih etmiyor, en güzeli yazarlardan oluşan bir grubu destinasyona getirip ă̆ırlamak, işletmeler ve bölge hakkında haber yapmasını sağlamak".

\subsection{Tanitım}

Yurtiçi ve yurtdışı basında işletmeyle ilgili haber yapılması \% 73.9 'la yöneticiler tarafından en çok tercih edilen tanıtım aracidir.

"Bir konuğumuz gece geç saatte Bloody Mary istedi. Taze domateslerden güzel bir kokteyl hazırlayıp kendisine sunduk, çok beğendiğini daha önce hiç böylesini içmediğini söyledi biz de mutlu olduk. Yaklaşık 1 ay sonra İngiltere'nin en çok okunan seyahat dergilerinden birinde bizimle ilgili müthiş bir köşe yazısının çıktığını öğrendik. Bloody Mary 
isteyen o müşteri İngiliz bir gazeteci imiş ve kimliğini gizleyerek otelimizde konaklamış ve çok memnun ayrllmış. Çok yüksek bir bütçe ayırsak bile bu tanıtımı yapamazdık".

Katılımcılardan \%52.1' i satış ve tanıtım için bir acente ile çalıştıklarını ancak müşterilerin otele gelirken acente kullanmayı çok tercih etmediklerini belirtmiştir. Ulusal ve uluslararası fuarlara katılımın tanıtım açısından gerekli olduğunu düşünenler \%47.8 oranındadır. Bu gibi etkinliklerin işletmenin faaliyette bulunduğu destinasyon tarafından yapılması ile artacağını ifade etmişlerdir.

\subsection{Elektronik Ortam Pazarlamast}

Görüşmelere katılan küçük konaklama işletmelerinin tümü otelin kendine ait web sayfasının; rezervasyon, satış, tanıtım gibi tüm işlemlerin gerçekleştirilebilmesi nedeniyle önemli olduğunu belirtmişlerdir.

"Müşteri otelin adını duyduğunda hemen web sayfasını açıyor, hem rakiplere fark atmak hem de müşteriyi etkilemek için sayfa çok önemli".

Tüketiciye çok daha hızlı ulaşmak ve modern pazarlama araçlarından geri kalmamak için twitter, instagram, facebook vb. sosyal medya araçlarını kullandıklarını belirten yöneticilerin oranı \%86.9'dur.

"Günümüz turisti her anını sosyal çevresi ile, özellikle de güzel vakit geçiriyorsa, paylaşmayı seviyor. Iç̧iği kahveyi, belki odasından bir görüntüyü ya da bahçedeki evcil hayvanımızın resmini anında sosyal medya hesabına ekliyor".

Booking, expedia, tripadvisor vb. çevrimiçi satış kanallarının katılımcılar tarafından kullanılma oranı \%78.2'dir. günümüz internet çağında çevrimiçi satış kanallarını yok saymanın mümkün olmadığını belirten katılımcılar, bu durumun kanallar tarafından olumsuz yönde kullanıldığını söylemişlerdir. Komisyonların çok yüksek olması, müşterinin oteli ismiyle taratıp rezervasyonu çevrimiçi kanal üzerinden yapması yöneticilerin olumsuz yönde önemle üzerinde durdukları konular arasında yer almaktadır.

"Booking'i mecburen kullanıyoruz eğer çıkarsak rakiplerimizin gerisine düşeriz. Oteli direkt arayan müşterilere booking'e ödediğim komisyon kadar indirim yapıyorum"

"her odamızı booking'e açmıyoruz ve haftasonları tamamen kapatıyoruz".

Katılımcılardan sadece \%8.6' sı çevrimiçi satış kanalı kullanmadığını ifade etmiştir.

\subsection{Müş̧teri Memnuniyeti ve Bă̆lılı̆̆}

Çalışmaya katılan yöneticilerin tamamı gelen misafirlerin kendileri tarafından karşılanmasının ve tatilleri süresince birebir iletişim kurmanın çok önemli olduğunu ifade etmiştir.

"Otel açıldı̆̆ından beri, 6 yıldır, gelen müşteriler var kapıdan girer girmez beni soruyorlar, göremeyince nerede hasta falan değil di mi diyorlar. Tatilleri süresince mutlaka çay, kahve içiyoruz sohbet ediyoruz".

\%60.8 oranında katılımcı müşterilerle ilgili veri tabanı oluşturmanın bağılılığın yaratılmasındaki önemini vurgulamıştır.

"Müşterilerle ilgili her türlü kaydı tutuyoruz. Otelimizde kutlama yapan konukları da kayıt altına alarak geçen yılki kutlamanızı bizimle yaptınız, bu yıl da bizimle olmaya ne dersiniz şeklinde cazip bir teklif eşliğinde arıyoruz ya da mesaj gönderiyoruz".

Özel günlerde (yılbaşı, bayram, doğum günü, yıldönümü) elektronik posta ya da kısa mesaj gönderimi \%65.2 oranında işletmeler tarafından tercih edilmektedir. Böylece müşteri ile iletişim sürekli hale getirilerek işletme sıklıkla hatırlatılmaktadır.

Katılımcıların \%56.2'si posta yolu ile eski müşterilere ulaşmanın bağlılık üzerinde etkisinin çok yüksek olduğunu ifade etmişlerdir.

"Otelde konaklayan küçük müşterilerimizden birkaç tanesinin burada yaptıkları resimleri kartpostal haline getirdik, özel günlerde bunlarl gönderiyoruz".

"Kendi el yazımla kart gönderiyorum, çok mutlu oluyorlar ve onlar da bana kart atıyorlar".

\section{Sonuç}

Pazarlama; işletmenin varlığını sürdürebilmesi, hedeflerini gerçekleştirebilmesi, daha kaliteli hizmet sunabilmesi için en önemli işletme fonksiyonlarından biridir. Etkin bir pazarlama faaliyeti ile konaklama işletmesinin piyasaya girmesi, müşterilerin memnun edilmesi yolu ile bağlılık oluşturulması ve bu tüketicilerin etkili bir pazarlama aracı haline gelmesi konaklama işletmeleri tarafından başarının anahtarı olarak görülmektedir. Küçük konaklama işletmeleri tarafından en çok tercih edilen pazarlama araçlarının ağızdan kulağa iletişim ve sosyal medya araçları olduğu saptanırken; birebir iletişimin müşteri bağlılığı üzerindeki etkisinin yüksek olduğu belirlenmiştir. Bu bulguların özellikle pazara yeni giren küçük konaklama işletmeleri için yol gösterici olacağı beklenmektedir.

Çalışma kapsamında İzmir şehir merkezi ve ilçelerinde butik hizmet sunan 23 küçük konaklama işletmesi sahibi ya da yöneticisi ile mülakat yapılmıştır. İşletmelerin pazarlama stratejileri ile ilgili ulaşılan bulgular değerlendirildiğinde büyük konaklama işletmelerine göre bazı farklılıklar göze çarpmaktadır. Büyük konaklama işletmelerinde bir pazarlama 
ve satış bölümü ve sadece bu konuda uzman personel bulunurken, küçük konaklama işletmelerinde bu fonksiyon sahip ya da yönetici ve tüm diğer personel tarafından yerine getirilmektedir. Çalışma sonucunda ulaşılan bu bulgular Filieri ve McLeay (2014)'in bulguları ile benzerlik göstermektedir. Küçük konaklama işletmelerinde müşteri memnuniyetine dayalı olarak etkinliği artan ağızdan kulağa pazarlamanın en fazla tercih edilen pazarlama aracı olduğu saptanmıştır.

Tüketicinin işletme hakkındaki yorumlarını çevresindeki potansiyel tüketicilerle paylaşması yolu ile gerçekleşen ağızdan kulağa pazarlama için işletmenin ek bir maliyete katlanması gerekmemektedir. Kaliteli ve iyi bir hizmet sunumu, müşteri isteklerine hızlı geri dönüş, evindeymiş hissi yaratma sonucu müşteri memnuniyeti oluşacak ve bu duygularla otelden ayrılan turist olumlu ağızdan kulağa iletişime geçecektir. Ülke ekonomisi krize girdiğinde bile ağızdan kulağa pazarlama başarılı bir araç olarak görülmektedir. Elde edilen bulgulara göre görüşülen işletme sahip ya da yöneticilerinin \% 86,9'u ağızdan kulağa pazarlamayı en etkili pazarlama aracı olarak görmektedir. Bu nedenle hem yöneticinin hem de diğer personelin turistin otelde olduğu süreç içerisinde en iyi hizmeti sunacak şekilde çalışması gerekmektedir. Mutlu müşteri çok iyi bir pazarlama aracıdır.Değişen tüketici eğilimleri doğrultusunda turistin daha sıcak ve samimi ilişkilerin kurulduğu küçük konaklama işletmelerini tercih ettiği elde edilen bulgular arasındadır. Büyük konaklama işletmelerinin kalabalığında kaybolmak istemeyen, kendisine özel hizmet arzulayan tüketiciler beş yıldızlı otel kalitesinde, hatta daha üst düzeyde, hizmet sunan küçük işletmelere yönelmektedir. Böylece yerel kültürü ve tatları yakından tanıma, samimi ilişkiler ve dostluklar kurabilme, özlediği ve ihtiyacını duyduğu sıcak bir ortamda vakit geçirebilme imkanına sahip olmaktadır.

Çalışma sonucunda ulaşılan bulgulara göre küçük konaklama işletmeleri tarafından sıklıkla başvurulan diğer pazarlama araçları da reklam ve tanıtımdır. Görüşmelere katılan işletmelerin yöneticileri iyi seyahat dergilerinde çıkan reklamların özellikle pazara giriş aşamasında oldukça etkili olduğunu belirtmişlerdir. Bu nedenle önce iyi bir reklam ajansıyla anlaşarak doğru zaman, yer ve mesajla hedef kitleye ulaşmak yöneticiler tarafından alınması gereken önemli ve etkili bir karadır. Sadece söz konusu işletme ile ilgili değil, destinasyonun tamamıyla ilgili tanıtım faaliyetinde bulunulması gerekliliği katılımcılar tarafından vurgulanan başka bir önemli noktadır. Çünkü turist sadece otelde vakit geçirmemekte dışarı çıkıp çevreyi gezmek istemektedir. Destinasyonun bir bütün halinde, eğer mümkünse duygusal bir hikaye eşliğinde tanıtılması hem yerel halkı hem de işletme sahiplerini motive ederek turizm sektörünün gelişmesi için daha çok çalışmalarını sağlayacaktır.

Modern pazarlama araçlarından biri olan elektronik pazarlama küçük konaklama işletmeleri için de düşük maliyetiyle oldukça cazip bir araçtır. Sertleşen rekabet koşulları müşteri üzerinde ilk izlenimi yaratacak olan işletmeye ait web sayfalarının önemini arttırmıştır. Müşteri ile her türlü iletişimin, pazarlama ve satışın gerçekleştirilebildiği web sayfalarının profesyonel kurumlar tarafından özenle hazırlanmasına dikkat edilmelidir. Mevcut ve potansiyel tüketicilerin yoğunlukla sosyal medya araçlarını kullanması işletmelerin de bu araçlardan uzak kalamamasına neden olmaktadır. Elde edilen bulgular Luo ve Zhang (2015)'in çalışmasıyla benzer özellikler göstermektedir. Çalışmaya katılan yöneticilerin bir kısmı ilk başlarda sosyal medyaya karşı mesafeli olduklarını ancak değişen koşullarla birlikte uyum sağlamaları gerektiğini anladıklarını ifade etmişlerdir. Doğru tekniklerle yönetilen sosyal medya hesapları işletmelere ciddi rekabet üstünlüğü sağlamaktadır.

Günümüz turistinin kendi tatilinin planlayıcısı olması sebebiyle çevrimiçi satış kanalları kullanımının arttığı ulaşılan bulgular arasındadır. Küçük konaklama işletmeleri tarafindan çok tercih edilen bir araç olmasa da tüketiciden gelen talep nedeniyle işletmeler çevrimiçi satış kanallarında yer almaktadır.

Çalışmaya katılan küçük konaklama işletmelerinin sahip ya da yöneticilerinin müşteri memnuniyeti ve bağlılığı hakkındaki görüşleri sorulduğunda tamamı kendileri tarafından karşılanma ve ilgilenmenin çok önemli olduğunu belirtmişlerdir. Birebir ilgi ve rahatlık isteyen tüketiciler tarafından tercih edilen küçük işletme sahip ya da yöneticilerinin personelleriyle birlikte bu konu üzerinde önemle durmaları gerekmektedir. İşletmede konaklayan müşterilerle ilgili veri tabanı oluşturma ve iletişimin sürekli hale getirilmesi hem tekrar tüketim hem de potansiyel müşterilere ulaşmak için gerekli bir uygulamadır. Özel günlerde işletmenin çeşitli araçlar kullanarak müşteriye kendisini hatırlatması, otelin varlığını sürdürebilmesi adına akılcı bir davranış olacaktır.

İşletmeye gelen konuğun konaklaması sırasında gerek personel gerekse sunulan ürünlerin kalitesi ile memnun edilmesi, bunun sonucunda müşteri bağlılığının oluşması küçük konaklama işletme yöneticilerinin kesinlikle göz ardı etmemesi gereken unsurlardır. Çünkü memnun ve sadık müşteri; en düşük maliyetli, en samimi ve en inandırıcı pazarlama aracidır.

Araştırma İzmir ilinde faaliyet gösteren 23 küçük konaklama işletmesinin sahip ya da yöneticilerinin görüşleri ile sınırlıdır. Daha sonra yapılacak çalışmalarda bu sayının arttırılması, bölge ya da ülke genelinde detaylı araştırmaların yapılması mümkündür. Ayrıca yönetici bakış açısıyla ulaşılan bu çalışma bulgularının gelecekte müşteri ile yapılacak çalışmalarla karşılaştırılması, böylece pazarlama stratejilerinin belirlenmesi ve müşteri bağlılığı konusunda daha net fikirlerin ortaya konmasının mümkün olacağı tahmin edilmektedir. 


\section{KAYNAKÇA}

Abbey, James. 1998. Hospitality Sales And Marketing. 3. Bask1. Michigan: AH\&MA.

Arlı, Erdal. 2012. "Müşterilerin Kulaktan Kulağa İletişime Bağlı Satın Alma Kararları Üzerinde Referans Gruplarının Etkisi: Deniz Turizm İşletmeciliği Üzerine Bir Araştırma.” Uluslararası Yönetim İktisat ve Işsletme Dergisi 8 (17): $155-170$.

Barutçu, Süleyman ve Tomaş, Melda. 2013. "Sürdürülebilir Sosyal Medya Pazarlaması ve Sosyal Medya Pazarlaması Etkinliğinin Ölçümü.” (IUYD) İnternet Uygulamalarl ve Yönetimi Dergisi 4 (1): 5-23.

Benur, Abdelati ve Bramwell, Bill. 2015. "Tourism product development and product diversification in Destinations." Tourism Management 50: 213-224.

Bowen, John ve McCain, Shiang-Lih Chen. 2015. "Transitioning loyalty programs A commentary on "the relationship between customer loyalty and customer satisfaction." International Journal of Contemporary Hospitality Management 27(3): 415-430.

Buttle, Francis. 1998. "word of Mouth Understanding and Managing Refferral Marketing." Journal of Strategic Marketing 6: 241-254.

Confente, Ilenia. 2015. "Twenty-Five Years of Word-of-Mouth Studies: A Critical Review of Tourism Research."

International Journal of Tourism Research 17: 613-624.

Derbaix, Christian ve Vanhamme, Joelle. 2003. "Inducing Word of Mouth by Eliciting Surprise- A Pilot Investigation." Journal of Economic Physcology 24(1): 99-116.

Dolnicar, Sara ve Ring, Amata. 2014. " Tourism marketing research: Past, present and future." Annals of Tourism

Research 47: 31-47.

Eröz, Sibel ve Doğdubay, Murat. 2012. “Turistik Ürün Tercihinde Sosyal Medyanın Rolü ve Etik İlişkisi.” Dokuz Eylül Üniversitesi İktisadi ve İdari Bilimler Fakültesi Dergisi 27 (1): 133-157.

Filieri, Raffaele ve McLeay, Fraser. 2014. "E-WOM and Accommodation: An Analysis of the Factors That Influence Travelers' Adoption of Information from Online Reviews." Journal of Travel Research 53(1): 44-57.

Fornell, Claes. 1992. “A National Customer Satisfaction Barometer: The Swedish Experience.” Journal of Marketing 56 (1): 6-21.

Güler, Emel. 2009. "Sürdürülebilir Sosyal Medya Pazarlaması ve Sosyal Medya Pazarlaması Etkinliğinin Ölçümü." Marmara Üniversitesi I.I.'B.F. Dergisi 17 (2): 233-261.

Goeldner, C. Ve Ritchie, J. 2003. Tourism: Principle, Practices, Philosophies. 9. Bask1. NewYork: Wiley.

Hacığlu, Necdet. 1991. Turizm Pazarlaması. 2.Baskı. Bursa: Uludağ Üniversitesi Basımevi.

Hudson, Simon ve Thal, Karen. 2013. "The Impact of Social Media on the Consumer Decision Process: Implications for Tourism Marketing." Journal of Travel \& Tourism Marketing 30: 156-160.

İçöz, Orhan. 2001. Turizm İşletmelerinde Pazarlama Illkeleri ve Uygulamalar. Ankara: Turhan.

İçöz, Orhan. 2005. Hizmet Pazarlamasl. Ankara: Turhan.

Kandampully, Jay, Zhang, Tingting ve Bilgihan, Anil. 2015. "Customer loyalty: a review and future directions with a special focus on the hospitality industry." International Journal of Contemporary Hospitality Management 27(3): 379-414.

Karamehmet, Bilge. 2013. "Mobile Marketing Communication in Tourism: A Case StudyFromTurkey." International Journal of Social Science 6 (7): 581-595.

Kılıç, Burhan ve Eleren, Ali. 2009. "Turizm Sektöründe Hizmet Kalitesi Ölçümü Üzerine Bir Literatür Araştırması.” Alanya Işletme Fakültesi Dergisi 1 (1): 91-118.

Kim, MiRan, Vogt, Christine ve Knutson, Bonnie. 2015. "Relationships Among Customer Satisfaction, Delight, and Loyalty in The Hospitality Industry." Journal of Hospitality \& Tourism Research 39(2): $170-197$.

Kobylanski, Andrzej. 2012. "Attributes And Consequences Of Customer Satisfaction In Tourism Industry: The Case Of Polish Travel Agencies." Journal of Service Science 5(1): 29-42.

Kotler, Philip, Bowen, John ve Makens, James. 1996. Marketing for Hospitality And Tourism. Upper Saddle River, NJ: Prentice Hall.

Kozak, Nazmi.2010. Turizm Pazarlaması. Ankara: Detay Yayıncılık.

Kozak, Nazmi. 2014. Turizm Pazarlaması. 6. Bask1. Ankara: Detay.

Kozak, Nazmi. (Ed.). Çakıı,, Celil, Kozak, Meryem, Azaltun, Murat, Sökmen, Alptekin ve Sarışı, Mehmet 2002. Otel Işletmeciliği. Ankara: Detay.

Kutluk, Ayşegül ve Avcıkurt, Cevdet. 2014. “Ağızdan Ağıza Pazarlamanın Müşterilerin Satın Alma Karar Süreçlerine Etkisi ve Bir Uygulama: (İstanbul Seyahat Acenteleri Örneği)." Uluslararası Sosyal Araştırmalar Dergisi 7 (29): 613-622.

Luo, Qiuju ve Zhong, Dixi. 2015. "Using social network analysis to explain communication characteristics travel-related electronic word-of-mouth on social networking sites." Tourism Management 46: 274-282.

Navickas, Valentinas ve Malakauskaite, Asta. 2009. "The Possibilities for the Identification and Evaluation of Tourism Sector Competitiveness Factors" Engıneerıng Economıcs 1 (61): 37-44. 
Olalı, Hasan ve Timur, Alp. 1988. Turizm Ekonomisi. İzmir: Ofset Ticaret Matbaacilık.

Olalı, Hasan ve Korzay, Meral. 1993. Otel Işsletmeciliği. İstanbul: Beta Basım Yayım Dağıtım.

Oliver, Richard L. 1980. "A Cognitive Model of theAntecedentsandConsequences of SatisfactionDecisions.” Journal of Marketing Research 17 (4): 460-469.

Özel, Çağıl Hale. 2012. Otelcilik Endüstrisi. Meryem Akoğlan Kozak (Ed), Otel İşletmeciliği içinde, ss. 1-28. Ankara: Detay.

Özer, Özgür ve Günaydın, Yusuf. 2010. “Otel İşletmelerinde Müşteri Memnuniyeti ve Müşteri Sadakati İlişkisi: Dört Yıldızlı Otel İşletmelerinde Bir Uygulama.” İşletme Fakültesi Dergisi 11 (2): 127-154.

Öztürk, Yüksel ve Seyhan, Kadir. 2005a. "Konaklama İşletmelerinde Sunulan Hizmet Kalitesinin Servqual Yöntemi İle Ölçülmesi." Anatolia: Turizm Araştırmaları Dergisi 16 (2): 170-182.

Öztürk, Yüksel ve Seyhan, Kadir. 2005b. "Konaklama İşletmelerinde Sunulan Hizmet Kalitesinin Artırılmasında İşgören Eğitiminin Yeri ve Önemi.” Ticaret Turizm Eğitim Fakültesi Dergisi 1: 121-140.

Papadimitriou Dimitra, Kaplanidou, Kyriaki ve Apostolopoulou, Artemisia. 2015. "Destination Image Components and Word-of-mouth Intentions in Urban Tourism: A Multigroup Approach." Journal of Hospitality \& Tourism Research 20 (1): 1-25.

Parasuraman, A., Zeithaml, A. Valarie ve Berry, L. Leonard. 1985. “A Conceptual Model of Service Quality and Its Implications for Future Research.” Journal of Marketing 49: 41-50.

Sarışık, Mehmet ve Özbay, Gülçin. 2012. "Elektronik Ağızdan Ağıza İletişim ve Turizm Endüstrisindeki Uygulamalara İlişkin Bir Yazın İncelemesi.” Uluslararası Yönetim İktisat ve Işsletme Dergisi 8 (16): 1-22.

Selvi, M. Selim ve Ercan, Fatih. 2006. “Otel İşletmelerinde Müşteri Sadakatinin Değerlendirilmesi: İstanbul'daki Beş Yıldızlı Otel İşletmelerinde Bir Uygulama.” Balıkesir Üniversitesi Sosyal Bilimler Dergisi 9 (15):159-188.

Stokes, David ve Lomax, Wendy. 2002. "Taking Control of Word-of-Mouth Marketing: The Case of an EntrepreneurialHotelier." Journal of Small Business and Enterprise Development 9 (4): 349-357.

Şahin, Gonca ve Şengün, Günce. 2015. "The Effects of Social Media on Tourism Marketing: A Study among University Students." Management and Administrative Sciences Review 4 (5): 772-786.

Şanlı̈̈z, H. Kader, Dilek, S. Emre ve Koçak, Nilüfer. 2013. "Değişen Dünya, Dönüşen Pazarlama: Türkiye Turizm Sektöründen Öncü Bir Mobil Uygulama Örneği.” Anatolia: Turizm Araştırmaları Dergisi 24 (2): 250-260.

Taplin, Ross. 2013. "The influence of competition on visitor satisfaction and loyalty." Tourism Management 36:238246.

Taş, İlkay. 2015. Otel İşletmeciliği. Timur, Alp ve Bardakoğlu, Övünç.(Ed) Turizm İşletmeciliği içinde. Ankara:

Detay Yayıncilik. ss. 45-62.

Tek, Baybars. 1999. Pazarlama İlkeleri Global Yönetimsel Yaklaşım Türkiye Uygulamaları. 8. Bask1. İ̀stanbul:

Beta.

Tütüncü, Özkan. 2001. Yiyecek İçecek İşletmelerinde Müşteri Tatminin Ölçülmesi. Ankara: Turhan.

Usta, Öcal. 2008. Turizm Genel ve Yapısal Yaklaşım. Ankara: Detay Yayıncılık.

Wong, Anthony ve Dioko, Leonardo. 2013. "Understanding the mediated moderating role of customer expectations in the customer satisfaction model: The case of casinos." Tourism Management 36: 188-189.

Yıldırım, Ali ve Şimşek, Hasan. 2008. Sosyal Bilimlerde Nitel Araştırma Yöntemi. Ankara: Seçkin Yayınevi. 